Article: [Reading Sallust in Twelfth-Century Flanders'

Author: $\quad$ Dr Andrew J. Turner

Affiliation: The University of Melbourne

Status: Honorary Research Fellow, Adjunct Lecturer

Address: $\quad$ School of Historical and Philosophical Studies

Old Quadrangle Building

The University of Melbourne

Parkville, 3010

Australia

Email: $\quad$ ajturner@unimelb.edu.au

Web: $\quad$ https://unimelb.academia.edu/AndrewTurner

http://www.findanexpert.unimelb.edu.au/display/person14091

\title{
Reading Sallust in Twelfth-Century Flanders
}

There can be little doubt that the two short historical tracts of Sallust (C. Sallustius Crispus), Bellum Catilinae $(B C)$ and Bellum Iugurthinum $(B J)$, quickly attained their prominent place in the Roman educational curriculum because of admiration for language - most notably Sallust's construction and placement of speeches, his use of rhetorical figures to highlight antitheses or urgency of action, his concision, and his striking use of archaic forms. Aulus Gellius in his Noctes Atticae defends 'the elegance of Sallust's speeches and his eagerness to invent or revive words' ('elegantia orationis Sallustii uerborumque fingendi et nouandi studium' [IV.15.1]) against the attacks of some anonymous critics; in the Controversiae of the Elder Seneca we read that (for otherwise busy readers) 'the speeches of Sallust are read as a

\footnotetext{
* The research for this article was undertaken in 2011/12 while I was a visiting fellow at the Vlaams Academisch Centrum in Brussels, working on the project 'Classical Scholarship in Mediaeval Flanders'. I would like to thank the staff and fellows there for all the assistance they gave me, and in particular my colleague, Professor Steven Vanderputten of Universiteit Gent, whose detailed knowledge of the sources and intellectual issues involved were of enormous benefit to me. I would also like to thank Dr Ann Kelders of the Royal Library in Brussels for her great assistance with images, and from my own university Professor Bernard Muir, for his knowledge of manuscripts and some meticulous proof-reading, and Dr Frederik Vervaet, for his answers on Roman republican questions. The anonymous reviewer for IJCT also provided useful corrections and tips, which I gratefully acknowledge.
} 
sign of respect to his Histories' ('orationes Sallustii in honorem historiarum leguntur' [exc. 3. pr. 8]); while Quintilian himself refers in the Institutio oratoria to 'that Sallustian concision, more perfect to a learned listener at his leisure than anything else could be' ('illa Sallustiana breuitas, qua nihil apud aures uacuas atque eruditas potest esse perfectius' [X.1.32]). By the time of Priscian in the early sixth century, the works were being extensively mined for exemplary as well as rare constructions; in Heinrich Keil's edition of Priscian in Grammatici Latini the five books of the Historiae are cited some sixty three or so times, while significantly the $B C$ is quoted fifty three times and the $B J$ some thirty one. The two short works were thus already established as fundamental educational classics before the end of the Roman world.

Another factor undoubtedly ensuring the survival of these works in the post-classical period was the interest of Christian scholars in Sallust's depiction of factional strife and his scathing criticism of the decline of morality during the age of Sulla. This factor, combined with admiration for his literary skills, clearly influenced Augustine while he was writing De ciuitate Dei, where he states:

quantis malis morum, quae secundis rebus exorta sunt, usque ad bella ciuilia demonstret esse peruentum [citing Sallust, Historiae frg. 1.16] ... dicit deinde plura Sallustius de Sullae uitiis ceteraque foeditate rei publicae, et alii scriptores in haec consentiunt, quamuis eloquio multum impari (Augustine, De ciuitate Dei, II.18) [Let him show us (in his own words) from what great wickedness of character, which arose when affairs were favourable, matters came right down to civil war ... Sallust then says many things about the vices of Sulla and the other foul behaviour of the res publica, and other writers agree with these words, although with an eloquence which is in no way equal to his.]

Augustine is writing here about the Historiae, which now survive only in scattered fragments, ${ }^{1}$ but he frequently cites parts of both the $B C$ and $B J$ as well, utilizing in particular those passages of the two works which offer reflective assessments of the decline of the Roman state and its mores, such as the preface to the $B J .^{2}$ As Robert Stein noted in his

\footnotetext{
${ }^{1}$ For discussion of the survival of the larger fragments, see L. D. Reynolds, 'Sallust', in Texts and Transmission: A Survey of the Latin Classics, ed. L. D. Reynolds, Oxford, 1983, pp. 341-9 (347-9).

${ }^{2}$ For discussion of the development of Augustine's interest in Sallust, the type of text he used and the passages he cited, see H. Hagendahl, Augustine and the Latin Classics, 2 vols, Göteborg, 1967, II, pp. 631-49, and in particular pp. 637-8, where he identifies BC 1-16.4, 51-4 (Caesar's and Cato's speeches), BJ 1-4, and Historiae 1.1 as passages of great interest to Augustine. Note also his summation: 'Catiline is represented as the very prototype of a scoundrel' (p. 646). For further discussion, see R. M. Stein, 'Sallust for his Readers, 410-1550: A Study in the Formation of the Classical Tradition', PhD diss., Columbia University, 1977, pp. 11-69.
} 
dissertation on this topic, Augustine's use of Sallust in De ciuitate Dei was initially driven by his need to refute pagan claims that Christianity was directly responsible for the sack of Rome in $408 \mathrm{AD}$, although he found in the earlier historian an important model and rich resources for his own speculations about the inner nature of earthly power which he then developed and powerfully transformed. ${ }^{3}$

Nevertheless, the subject matter of both works must have appeared quite foreign to medieval readers lacking any detailed knowledge of the Roman constitution and the history of the expansion of Roman imperium, other than that already provided by Augustine. The $B C$ certainly engages with universal themes of corruption and decline, but the narrative of Catiline's own attempts to gain the consulship, Cicero's questionable actions against him and his supporters, and even the central debate of Caesar and Cato, are expressed in a language rooted in late Republican political life. And despite explicit references to the moral decline of the res publica in the $B J$, particularly in its preface and speeches, the main thrusts of this work are military history and, in the background, the incipient conflict for control of the army between the nobiles, represented by Metellus and Sulla, on the one hand, and the populares, represented by Marius, on the other, and in order to understand these background politics fully readers would have required knowledge of the complex systems of annual magistracies and popular assemblies in late republican Rome. Given the large number of barbarian names and the local history and geography which appear in this work as well, one might have expected a detailed commentary tradition to have evolved in the late antique period pari passu with the diffusion of the text as a teaching tool, although as far as we can tell (in light of our very limited present-day knowledge of this topic), this was not the case; we know of only one exegetical work from antiquity, that of the late second-century AD grammarian Aemilius Asper (which may in any case have dealt only with the Historiae), ${ }^{4}$ and such commentaries as do exist did not start circulating until the twelfth century, as will be discussed below.

One partial exception to this tendency seems to have come with the tradition of the ' $\mathrm{T}$ ' map. The ' $\mathrm{T}$ ' map is originally a simple schematic device consisting of a circle surrounding a T-shape which divides it into three parts, characteristically labelled 'Asia' (top), 'Europa' (lower left) and 'Africa' (lower right); usually the arms of the T are also labelled 'Tanais'

\footnotetext{
${ }^{3}$ See Stein (n. 2), pp. 21-2, 46-9.

${ }^{4}$ For discussion of its scope and the extant fragments, see P. J. Osmond and R. W. Ulery, 'Sallustius', in Catalogus translationum et commentariorum; Mediaeval and Renaissance Latin Translations and Commentaries; Annotated Lists and Guides, VIII, ed. V. Brown, Washington DC, 2003, pp. 183-326 (301-2). For Asper's dates, P. L. Schmidt, 'Aemilius Asper', in Brill's New Pauly, ed. H. Cancik and H. Schneider, II, Leiden, 2003, col. 218.
} 
(dividing Asia from Europe) and 'Nilus' (dividing Africa from Asia). Its earliest extant examples occur in manuscripts of Isidore of Seville, although it soon spread to other, quite diverse genres, such as Christian world chronicles; in classical literary works, it is found in both the $B J$ and Lucan's Pharsalia. ${ }^{5}$ It seems to have circulated in association with the $B J$ at least since the eleventh century and perhaps earlier, ${ }^{6}$ and is used to illustrate chapters $17-19$ of the $B J$, where Sallust famously breaks off his narrative to give a concise geographic and ethnographic account of Africa, beginning:

In diuisione orbis terrae plerique in parte tertia Africam posuere, pauci tantummodo Asiam et Europam esse, sed Africam in Europa (BJ 17.3)

[In dividing the sphere of the earth many (authorities) have placed Africa in the third part, and few (argue) that there is simply Asia and Europe, but that Africa (is situated) in Europe.]

In many relatively early Sallust manuscripts, the map appears as a simple diagram in the margin beside the relevant text, although already by the later part of the eleventh century a full page is allocated in some witnesses and, as the available space increases, so too does the detail; cities, particularly Rome or Jerusalem, begin to be indicated, or tribes listed. ${ }^{7}$

The amount of material which needs to be studied in detail in order to understand properly the reception of these two works in the medieval period is vast; and although some general surveys are now available, including two dissertations and a useful overview by Yanick Maes, there are many areas which remain uncharted. ${ }^{8}$ There have, however, been two recent publications which have assisted matters considerably. The first is the 2003 contribution of Patricia Osmond and Robert Ulery in the Catalogus translationum et commentariorum, ${ }^{9}$ which provides a listing and discussion of the various later medieval commentary traditions, including identifications of relevant manuscripts and a full bibliography. This work is

\footnotetext{
${ }^{5}$ For discussion of its origins and diffusion, see W. M. Stevens, 'The Figure of the Earth in Isidore's "De natura rerum", Isis, 71, 1980, pp. 268-77; A. D. von den Brinken, 'Mappa mundi und Chronographia: Studien zur imago mundi des abendländischen Mittelalters', Deutsches Archiv für Erforschung des Mittelalters, 24, 1968, pp. 118-86, esp. 128-31; P. Gautier Dalché, 'De la glose à la contemplation: Place et fonction de la carte dans les manuscrits du Haut Moyen Âge', in Testo e immagine nell'alto Medioevo, 2 vols, Spoleto, 1994, II, pp. 693-771. ${ }^{6}$ For the dates see Gautier Dalché (n. 5), p. 707.

${ }^{7}$ For the former type, see MS Munich, Bayerische Staatsbibliothek [hereafter, BSB], clm 4559 (11th century) fol. 20 , and MS Vatican City, Biblioteca Apostolica Vaticana [hereafter, BAV], lat. 3325 (10th century) fol. 24 ${ }^{\mathrm{r}}$ For the later, see the discussions of MS Oxford, Bodleian Library, MS Rawlinson G.44 (11th century), fol. $17^{\mathrm{v}}$, and Deventer, SAB, $11 \mathrm{~F} 1\left(12 / 13^{\text {th }}\right.$ century), fol. $1^{\mathrm{r}}$ later in this article.

${ }^{8}$ Besides the dissertation of Stein (n. 2), there is now the work of Étienne Rouziès, 'Lectures médiévales de Salluste', Thése diplôme d'archiviste-paléographe, Paris-ENC, 2004 (online summary available at http://theses.enc.sorbonne.fr/2004/rouzies). For Maes, see 'Sallust', in Brill's New Pauly, Supplement: The Reception of Classical Literature, ed. C. Walde, Leiden, 2012, pp. 370-8.

${ }^{9}$ Osmond and Ulery (n. 4).
} 
particularly useful in understanding the development and circulation, from the twelfth century onwards, of a series of anonymous commentaries to the $B C$ and $B J$ which appeared in Germany and southern Flanders; as Ulery (responsible for the earlier part of this study) notes, several of these works, particularly those from Bavaria, appear to have been influenced by scholastic thought. ${ }^{10}$ The second is the detailed study by Carmen Cardelle de Hartmann of manuscripts and commentaries from the German monastery of St Emmeran in Regensburg, ${ }^{11}$ the scriptorium of which was the distribution point for two of the earliest complete commentary texts. Cardelle de Hartmann's study, with its detailed codicological descriptions and its emphasis on usage of manuscripts within scriptoria, also provides a useful model for further investigations of this kind, particularly when dealing with the issue of the corrected text of the $B J-$ a large chunk (BJ 103.2 ['quinque delegit'] to 112.3 ['et rotam']) had fallen out of the archetype of most witnesses written North of the Alps in the Carolingian period, and began to reappear in copies only from the eleventh century onwards..$^{12}$

The present study looks at the way in which Sallust manuscripts were read and studied in Flemish monasteries in the period prior to, or around, the initial diffusion of these commentary texts. I have roughly dated this preliminary stage in the title to this paper to the twelfth century, although some manuscripts considered here seem to have been written in the eleventh century or even earlier, and one other may be slightly later. By Flanders, I also mean the County of Flanders as it existed in this period; despite constant fluctuations in its boundaries, throughout the eleventh and twelfth centuries the Counts of Flanders maintained control over lands which extended well into present-day France, including important intellectual centres and libraries at Saint Omer (with its monastery of St Bertin and collegiate church of St Omer), and, on the south-eastern border, in the monasteries of the Scarpe valley (especially St Amand-en-Pévèle). ${ }^{13}$

It should be stressed at the outset that the spatial and temporal boundaries imposed here do not necessarily mean that there was a uniquely Flemish way of reading Sallust at this time, which somehow differed from German or Italian interpretations. Books and scholars could and did travel long distances from monastery to monastery; thus, the only extant copy of the

\footnotetext{
${ }^{10}$ E.g., the 'Anonymus Ratisbonensis A', described in Osmond and Ulery (n. 4), p. 227, as 'showing argumentation of a decidedly scholastic bent'.

${ }^{11}$ C. Cardelle de Hartmann, 'Sallust in St. Emmeran: Handschriften und Kommentare in der Bibliothek des Klosters St. Emmeran (Regensburg)', The Journal of Medieval Latin, 18, 2008, pp. 1-23.

${ }^{12}$ See L. D. Reynolds, 'The Lacuna in Sallust's Jugurtha', Revue d'histoire des textes, 14-15, 1984, pp. 59-69.

${ }^{13}$ For an overview of the political history of Flanders, see D. Nicholas, Medieval Flanders, London, 1992, esp. pp. 56-96. For a more detailed discussion of the role of the abbeys in the late 11 th century, see S. Vanderputten, 'Crises of Cenobitism: Abbatial Leadership and Monastic Competition in Late Eleventh-Century Flanders', English Historical Review,127, 2012, pp. 259-84.
} 
Latin versification of the Historia Apollinarii Regis Tyri, known as the Gesta Apollinarii, is found bound as flyleaves to an eleventh-century manuscript of Jerome's In Ezechielem from St Peter (now MS Ghent, Universiteitsbibliotheek, 169 [433], fols 233-4), and it has been argued that this poem was, in fact, written in the Tegernsee area of southern Bavaria. ${ }^{14}$ But there was always a strong interest in Sallust in Flanders, and particularly at this stage, judging by the number of surviving manuscript witnesses. As will be discussed in the following section, six witnesses are still extant which seem to have belonged to Flemish foundations in the eleventh and twelfth centuries, as well as a further manuscript from the Dutch monastery of Egmond, a foundation of monks from Ghent; by way of comparison, only two copies of the works of Terence, another staple of the medieval curriculum, can be definitely assigned to Flemish monasteries from the same period. ${ }^{15}$ Careful evaluation of the evidence, as constituted in corrections, additions, and early forms of scholia, may go some way towards explaining particular aspects of this popularity.

\section{THE EVIDENCE FOR DISTRIBUTION OF THE $B C$ AND $B J$ IN FLANDERS}

\section{a) The monasteries of the Scarpe valley}

It has already been noted that the monasteries of the Scarpe valley, despite their position on the border with the French kingdom, provided an important intellectual centre for the County of Flanders. In particular, despite a significant decline in the fortunes of St Amand during the eleventh century, ${ }^{16}$ the library of this monastery remained one of the great monuments of Carolingian scholarship, with a major collection of classical texts among its other possessions. It even seems possible that during the ninth century the library may have still preserved manuscripts from the late antique period; thus, it has been conjectured on good grounds that the monastery possessed a manuscript of Terence written in rustic capitals, ${ }^{17}$ although the extant copy, MS Valenciennes, Bibliothèque municipale [hereafter, BM] 448 [420], in fact, dates from the eleventh century. Two twelfth-century catalogues survive from

\footnotetext{
${ }^{14}$ See P. Godman, The Silent Masters: Latin Literature and its Censors in the High Middle Ages, Princeton NJ, 2000, pp. 37-41.

${ }^{15}$ MSS Leiden, Universiteitsbibliotheek, LIP 26 (from St Peter, Ghent), and Valenciennes, Bibliothèque municipale, 448 (from St Amand).

${ }^{16}$ See Vanderputten, 'Crises of Cenobitism' (n. 13), pp. 270-1.

${ }^{17}$ See D. Ganz, [Review article] 'D. H. Wright, The Lost Late Antique Illustrated Terence', Early Medieval Europe, 18, 2010, pp. 131-3, referring to the fifteen lines of the Heauton timorumenos in capitalis script copied into MS Paris, Bibliothèque Nationale de France [hereafter, BNF], lat. 2109 (from St Amand) as a probatio pennae.
} 
St Amand which both mention a manuscript of 'Sallustius', ${ }^{18}$ and this has been taken to refer to the surviving manuscript of the $B C$ and $B J$ from this monastery's collection, MS

Valenciennes, BM 549 [503], written in the first half of the twelfth century. ${ }^{19}$

The neighbouring monastery of St Rictrude at Marchiennes, originally founded as a nunnery but then reformed as a male house in $1024,{ }^{20}$ also possessed a fragment of a manuscript of the $B C$ in its library, now MS Douai, BM 749-III (fols $72^{\mathrm{r}}-79^{\mathrm{v}}$, containing $B C$ 1-45.1 ['comitatus deprehendant']), which was copied in the second half of the twelfth century. ${ }^{21}$ These two manuscripts have also been identified by Ulery as the only known copies of the family of Sallust scholia he and Osmond classify as Anonymus Amandensis, named after St Amand, ${ }^{22}$ although part of the proemium to the $B C$ is found in a twelfth-century codex from Normandy (MS Vatican City, BAV, Ottob. lat. 1843), which also contains a proemium to the $B J$ similar to that in one of the Ghent manuscripts; it will be discussed below in this context.

In his detailed description of the fragmentary text of Sallust contained in MS Douai, BM 747, André Boutemy showed through a number of sondages how both text and scholia in this manuscript were entirely consistent with the corresponding portion of Valenciennes, BM 549 [503], and he argued that the Douai manuscript was most probably copied at St Amand directly from the Valenciennes witness during the second half of the twelfth century, before being bound with a number of heterogeneous texts to form the present manuscript. ${ }^{23}$ My own collation has confirmed the very close relationship of the two texts of Sallust still further, ${ }^{24}$ and has shown, too, that many of the scholia are identical, right down to the system of abbreviations used. ${ }^{25}$ But while the Douai witness does not have any value for establishing textual readings of Sallust, its date provides a fairly certain terminus ante quem for composition of the Anonymus Amandensis. Moreover, its selection as an appropriate text to be copied at St Amand, as well as the inclusion of Sallust in a number of different florilegia from

\footnotetext{
${ }^{18}$ See B. Munk Olsen, L'étude des auteurs classiques latins aux xie et xiie siècles, 3 vols, Paris, 1982-1989, III, pp. 216-19.

${ }^{19}$ Ibid., II, p. 349.

${ }^{20}$ Vanderputten, 'Crises of Cenobitism' (n. 13), p. 262.

${ }^{21}$ For a full description, see A. Boutemy, 'Notice sur le manuscrit 749 de la Bibliothèque Municipale de Douai', Latomus, 3, 1939, pp. 183-206 and 264-98. See also Munk Olsen (n. 18), II, pp. 320-1.

${ }^{22}$ See Osmond and Ulery (n. 4), pp. 231-2.

${ }^{23}$ Boutemy (n. 21), pp. 184, 195-200.

${ }^{24}$ Very occasionally the Douai witness will agree with another Flemish manuscript and against the Valenciennes witness (e.g., in BC 20.1, where Douai 749 shares the reading 'imperatam' with MS Vat. lat. 3325 and against the correct reading imparatam in MS Valenciennes 549 [503]), but the infrequency of such parallels and the common nature of these types of error make it far more likely that they occurred by chance.

${ }^{25}$ The scholion in both witnesses to 'comitiis' from $B C 24.1$ discussed below is a good example of this; both manuscripts use exactly the same contractions for initial 'con' and abbreviations for 'quandoquidem' and 'omnes'.
} 
the area containing other classical, patristic, and biblical texts, ${ }^{26}$ provides further evidence for the value attached to his works as a means of linguistic instruction in the southern Flemish monasteries throughout this period. ${ }^{27}$ This production of literary materials also coincided with the production of fine manuscript copies of hagiographical works for the same monasteries, which can be associated with the process of monastic reform. ${ }^{28}$

Valenciennes, BM 549 [503] is a codex integer, that is, a manuscript which contains the complete text of the $B J$, including the missing passage $B J 103.2-112.3$ in the correct place. In this respect, the manuscript differs from many other witnesses from this area, which are known as suppleti (supplemented), since the missing text was written at some later stage as an addition, most usually on inserted sheets at the end of the manuscript. The fact that a manuscript is integer, however, is by no means a guarantee that its text is superior, since, as L. D. Reynolds noted, it could simply be a copy of a suppletus with the missing text included in the correct position; in this regard, he also commented that the 'the integri are so contaminated that they are best regarded as having an open tradition'. ${ }^{29}$ More interesting is the fact that the manuscript was corrected throughout this period, both before and after the Douai witness seems to have been copied from it, and these corrections often show readings found in other witnesses from the area. ${ }^{30}$

The commentary found in these two manuscripts, the Anonymus Amandensis, is prefaced with an accessus to the $B C,{ }^{31}$ a short introductory text designed to guide the readers' initial interaction with any literary work by defining it according to a number of broad categories (e.g., 'materies', 'subject matter'; 'intentio', 'aims'), simple questions ('quis', 'who'; 'quid', 'what') or 'causae' ('reasons'), which are then exemplified by the particular work; the

\footnotetext{
${ }^{26}$ Besides the Florilegium Duacense mentioned below (see the discussion of Sallust in St Omer), another extensive florilegium of classical texts is found in MS Douai, BM 747 itself, at fols $23^{\mathrm{r}}-61^{\mathrm{v}}$; see Boutemy (n. 21), pp. 187-9, for a description, and pp. 195-6 for his conclusion that the missing portion of the copy of the $B C$ in this manuscript was used as a source by the scribes who compiled the florilegium.

${ }^{27}$ For other evidence for the use of classical texts at Marchiennes during the 12th century, see the hagiographer Gualbert, active there between 1124 and 1130, who cited Juvenal in his Translatio S. Jonati; see S. Vanderputten, 'A Miracle of Jonatus in 1127: The Translatio sancti Jonati in villa Saliacensi (BHL 4449) as Political Enterprise and Failed Hagiographical Project', Analecta Bollandiana, 126, 2008, pp. 55-92 (7.22-23).

${ }^{28}$ For manuscripts containing the Vita et Miracula S. Dunstani of Eadmer which were written for St Rictrude in Marchiennes and St Sauveur in Anchin in the mid to late 12th century, see Eadmer of Canterbury, The Lives and Miracles of Saints Oda, Dunstan, and Oswald, ed. A. J. Turner and B. J. Muir, Oxford, 2006, pp. lxxix-lxxxi. ${ }^{29}$ Reynolds, Texts and Transmission (n. 1), pp. 341, 344.

${ }^{30}$ Thus, in $B C 3.3$ Valenciennes 549 inserts $a$ above the line before the phrase 'studio ad rem publicam', and this reading is also found incorporated in the text in MS Douai 747 and a witness from Ghent, MS Vatican City, BAV Reg. lat. 686; in $B C 3.5$ Valenciennes 549 originally agreed with another Ghent witness, MS BAV, Vat. lat. 3325, in writing 'ab reliquis malis', but the corrector expuncted 'reliquis' and corrected it above the line to the proper reading 'reliquorum', and this is also transmitted in the text of the Douai witness. In $B C 7.7$ Valenciennes 549 originally wrote 'trahat' for 'traheret', and this reading is found in the Douai witness, but a later corrector in Valenciennes 549 emended it above the line to the correct form.

${ }^{31}$ Found on fol. $1^{\mathrm{r}}$ of Valenciennes 549 and fol. $70^{\mathrm{r}}$ of Douai 749.
} 
Anonymus Amandensis belongs to the first group and provides abstract descriptions of the $B C .^{32}$ The Valenciennes witness also contains a ' $T$ ' map on fol. $1^{\mathrm{r}}$ which includes some illustrations of buildings but which is mostly devoid of place names (except for 'Asia' and 'Roma'), although a poorly legible hand of uncertain date also wrote along the 'Nilus' branch a few of the names from the geographic excursus of the $B J$ ('Leptis' and 'Arae Philenon' are still visible).

The commentary in the Anonymus Amandensis is described by Ulery as consisting of 'grammatical explanations and simple paraphrases of individual expressions', ${ }^{33}$ although it also provides, or attempts to provide, some historical background to Sallust's works. Thus, glossing the word 'comitiis' in the sentence 'Igitur comitiis habitis consules declarantur M. Tullius et C. Antonius' ('And so, when the comitia were held, Marcus Tullius [Cicero] and Gaius Antonius were declared consuls', $B C$ 24.1), the manuscripts explain:

quandoquidem periculum monuit ut fierent consules declarantur. comitia componitur ex con et eo is, quia quando consules fieri debebant conueniebant omnes in martio campo. $^{34}$

Whenever danger warned that there should be consuls they were declared. 'comitia' is constructed from 'con' and 'eo is', since when consuls needed to be created everyone came together in the Field of Mars.

The scholiast is incorrect in assuming that consuls were only appointed in times of danger (which the dramatic situation of the $B C$ may possibly have seemed to a medieval reader to imply), and is more interested in producing an etymology of the word comitia. But the fact that he also knew that comitia were conducted in the Campus Martius, or Field of Mars, for the election of consuls (technically, the comitia centuriata), points directly to use of another source. Later in the work, when Catiline's abortive attempt in $63 \mathrm{BC}$ to be elected consul for the following year is described, there is an indirect reference to the 'ambushes which [Catiline] had set for the consuls in the campus' ('insidiae quas consulibus in campo fecerat', $B C$ 26.5), but there is no mention of Martius here, no implication in this passage that this was where the elections took place, and, in fact, the phrase 'in campo' is missing in both the Valenciennes and the Douai manuscripts.

\footnotetext{
${ }^{32}$ See the opening comment: 'Totus liber iste uersatur in duobus contraiis; in defensore patriae et hoste, et hii duo sunt eius materia' ('this entire book turns upon two contrary men, the defender of the homeland and its enemy, and these two are its subject matter'). For discussion see Osmond and Ulery (n. 4), p. 231, and for a general account of this phenomenon in Sallust manuscripts, pp. 193-4.

${ }_{33}$ Osmond and Ulery (n. 4), p. 231.

${ }^{34}$ Valenciennes 549, fol. $6^{\mathrm{v}}$; Douai 747 , fol. $76^{\mathrm{r}}$.
} 
Earlier in the text, when Sallust had referred to a large number of Catiline's coconspirators coming 'ex coloniis et municipiis' $(B C$ 17.4), the commentary explains:

Colonias uocat nouas ciuitates, quia romani transferendo ciues mutauerunt ciuitates, et taliter quodammodo renouauerunt ciuitates. Municipia uocat castella, a quibus romani capiebant munera uel tributa. ${ }^{35}$

[He calls new cities coloniae, since the Romans changed cities by transferring citizens, and thus in a certain way they renewed cities. He calls castles municipia; by means of them the Romans used to receive duties (munera) or tributes.]

The gloss seems to be in part derivative of Isidore's definitions of coloniae and municipia (discussed below with regard to MS Vatican City, BAV, Vat. lat. 3325), but the point of the first explanation here is obscure. It appears to transmit a garbled memory of the process whereby the Romans would establish coloniae by importing populations of Roman citizens, particularly veterans, into captured cities, ${ }^{36}$ but it does not seem to know the correct explanation of the word, which derives from colonus ('farmer'), itself a derivative of colo ('cultivate'); this etymology was widely known in antiquity and, indeed, was cited by Augustine as well as Isidore. ${ }^{37}$ The second at least draws a clear etymological link between the words municipia and munus, although the proper root of municipia is in fact municeps ('a citizen who undertakes duties'), ${ }^{38}$ which derives from munia ('duties'), a cognate form of munus. The shift in interpretation here is noteworthy; municipia are no longer peaceful citizen bodies established within a legal framework which controlled all of Italy, but are understood as military foundations and the means of extracting tribute.

Many of these attempted historical explanations in the Anonymus Amandensis appear to be nothing more than inspired guesswork; thus in the $B J$, when Sallust mentions the brutal murder of one of the 'triumuiri coloniis deducendis' ('three men responsible for planting colonies'; $B J$ 42.1), the commentator explains: 'triumuirum uocamus qui tres uiros habet sub se, alii autem triumuirum trium ciuitatum procuratorem appellant' ('we call him a triumuir who has three men under his command; others, however, call the administrator of three cities

\footnotetext{
${ }^{35}$ Valenciennes 549, fol. $5^{\mathrm{r}}$; Douai 747, fol. $74^{\mathrm{v}}$.

${ }^{36}$ A variant of it appears again in the commentary on the $B J$; with regard to triumuirum coloniis deducundis (BJ 42.1), the commentary in Valenciennes 549 (f. $29^{r}$ ) states here: 'Colonia est noua ciuitas, et mos erat apud romanos ut in nouis ciuitatibus post xl dies familiae militum mutarentur' ('a colony is a new city, and it was the custom that after 40 days the companies of the soldiers would be changed').

${ }^{37}$ See Thesaurus Linguae Latinae [hereafter, TLL], Leipzig, 1900- , III, p. 1698. For Augustine, 'colonia dicta... est a colendo' (Augustine, De ciuitate Dei X.1); for Isidore, see below.

${ }^{38}$ See TLL, VIII, p. 1645 (municeps), 1648 (municipium).
} 
a triumuir' $).{ }^{39}$ What is perhaps more important here is the perceived requirement of twelfthcentury readers to understand the meaning of references to the institutions of the distant Roman past. Even if he did not have a specific desire to recount other details of Roman history, the compiler (or perhaps compilers) of the Anonymus Amandensis was at least aware at particular stages that the readers of the manuscripts disseminated from his scriptorium required some basic information in order to make sense of Sallust's narrative.

The commentary in Valenciennes 549 is in fact incomplete; the last entry occurs on fol. $36^{\mathrm{v}},{ }^{40}$ and the next 10 folios which follow, containing the last 36 chapters of the $B J$, are unglossed. At the conclusion of the $B J$ on fol. $46^{v}$, however, two scholiasts, roughly contemporary with the main hand of the manuscript, also copied in the margin a number of short definitions of political and military terms, mostly excerpted from Book IX of Isidore's Origines, with short interpolations from other, unknown sources; ${ }^{41}$ these same definitions were also copied on fol. $70^{\mathrm{r}}$ of Douai 747, its opening page. Sections of Isidore's work were used as sources for scholia in many Sallust manuscripts from the twelfth century, as was noted by Cardelle de Hartmann (particularly with regard to the manuscripts produced at St Emmeran), ${ }^{42}$ and as can be seen in the case of one of the extant witnesses from Ghent (discussed below).

\section{b) Ghent}

Ghent was dominated throughout the middle ages by two major monasteries, St Bavon and St Peter (also known as Blandinium), each of which claimed historical primacy, ${ }^{43}$ and each of which maintained important libraries. St Bavon possessed at one stage a manuscript of the $B C$ and $B J$, now held in the Vatican library (MS Vatican City, BAV, Reg. lat. 686); ${ }^{44}$ the provenance is provided by an ex-libris on fol. $1^{\mathrm{v}}$, dated to the twelfth or thirteenth century. ${ }^{45} \mathrm{It}$ does not appear to have been recorded in the extant library catalogue of $c .1450,{ }^{46}$ and so may

\footnotetext{
${ }^{39}$ Valenciennes 549, fol. $29^{\mathrm{r}}$.

${ }^{40}$ Glossing 'nam duo sunt sinus' ('for there are two gulfs'; $B J$ 78.2).

${ }^{41}$ Beginning 'Consules dicti sunt uel a consulando ciuibus' (cf. Isidore, Origines IX.3.6); the first hand continues to 9.3.64 ('agmen dicitur ab a[u]gendo'). The second scholiast overlaps with the first, beginning 'Excubitores dicti' (9.3.42) and concluding 'patres conscripti uocati' (9.4.11); he provides definitions of quaestor and supplicia not included in the standard editions of Isidore.

${ }^{42}$ See Cardelle de Hartmann (n. 11), p. 11 and esp. n. 37.

${ }^{43}$ See P. Schmitz, 'Mont-Blandin', in Dictionnaire d'histoire et de géographie ecclésiastiques [hereafter, DHGE], Paris, 1912- , IX, cols 118-29, esp. 121.

${ }^{44}$ Described in E. Pellegrin et al., Les manuscrits classiques latins de la Bibliothèque Vaticane, 3 vols, Paris, 1975-2010, II.1, pp. 95-7; Munk Olsen (n. 18), II, pp. 352-3.

${ }^{45}$ For the date of the ex-libris, see Munk Olsen (n. 18), II, p. 352.

${ }^{46}$ Printed in A. Derolez et al., Corpus catalogorum Belgii: The Medieval Booklists of the Southern Low Countries, 7 vols, Brussels, 1994-, vol. 3, pp. 72-97; see also the discussion of the library based on this list at pp. 48-51.
} 
have been removed from the collection prior to that date, although it later came into the possession of the Flemish Protestant reformer Filips van Marnix (d. 1598). ${ }^{47}$

The manuscript itself has been dated by Munk-Olsen to the second half of the twelfth century. ${ }^{48}$ The copy itself was poorly executed, with numerous errors and omissions which were corrected at various stages in its history. ${ }^{49}$ In particular, a passage of some 320 words from the $B J(B J 41.6$ ['ceterum nobilitas']-43.3 ['militiae parare']) was initially omitted by the copyist, and was only supplied on an inserted slip (now fol. 25 bis) by a corrector from the end of the twelfth century. The same corrector seems also to have supplied fols 41-42 of the manuscript, containing the conclusion of the $B J$ (BJ 102.5 ['dinem, pariter']-114); ${ }^{50}$ given that this part of the work contains all of the text omitted in most earlier witnesses (i.e. 103.2112.3), it seems plausible (although by no means certain) that in the original copy the passage had been omitted, and that the corrector simply removed the last folio or folios and replaced them with a bifolium with the text written in the correct order, thus making the manuscript a codex mutilus suppletus (a manuscript of Sallust with the missing text of the $B J$ inserted). This replacement text is also characterized by a very high number of transmission errors and variants, ${ }^{51}$ which may either reflect the poor quality of scholarship at this scriptorium or else defects in the exemplar.

The manuscript does not have an accessus, and contains only a few scattered glosses in a hand dated to the end of the twelfth century, particularly on fols $19^{\mathrm{v}}-20^{\mathrm{r}}$, where nearly all of Sallust's geographic and ethnographic excursus on Africa is found (BJ 17.3-19.7), although unfortunately these are highly abbreviated and now poorly legible. Before the text was copied, a circle was inscribed covering the top half of fol. $19^{v}$, presumably in order to draw a ' $\mathrm{T}$ ' map, although this map was never completed.

Turning to the library of St Peter, although no medieval catalogue survives, ${ }^{52}$ we know that before the Reformation it would have possessed a rich collection, including many classical

\footnotetext{
${ }^{47}$ Pellegrin et al. (n. 44), II.1, p. 96.

${ }^{48}$ Munk Olsen (n. 18), II, p. 352.

${ }^{49}$ See fol. $22^{\mathrm{r}}$, where a passage omitted from $B J 29.6$ ['pro consilio...pondere'] was supplied in the margin by a corrector, although parts of it were then lost when the page was cropped.

${ }^{50}$ For the identification of these two sections as the same hand, see Pellegrin et al. (n. 44), II.1, p. 96; for the date, Munk Olsen (n. 18), II, p. 352.

${ }^{51}$ In my collation of variants in Valenciennes, BM 549, Reg. lat. 686 and Vat. lat. 3325 (from St Peter), just for the portion of $B J 103$ which belongs to the replacement text there are fourteen variants from the Teubner text of Kurfess, and ten of these are found in Reg. lat. 686 alone.

${ }^{52}$ The few meagre and partial lists of books to survive from the $15^{\text {th }}$ century are collected in Derolez et al. (n. 46), III, pp. 111-15.
} 
works. ${ }^{53}$ As late as the mid-1560s it owned four antiquissimi or 'extremely old' copies of Horace, which the abbot loaned to Jacob Crucq of Bruges for his critical edition of Horace's works. ${ }^{54}$ Other surviving manuscripts of classical or late antique authors St Peter owned during the twelfth century, when a characteristic anathema was added to them, include works by the mythographer Hyginus, Martianus Capella (two copies), Nonius Marcellus, Vegetius, ${ }^{55}$ and Terence. The manuscript of Terence, now Leiden, Universiteitsbibliotheek, LIP 26, is a particularly important book; almost certainly written at St Peter during the rule of Wichard (prior from 1029, and abbot from 1034/5 to 1058), it includes several illustrations of scenes from the plays which derive from a cycle of illustrations generally acknowledged to date back to Late Antiquity, and is also a rich source for scholia and other scholarship. Works cited in marginal comments written during the eleventh or twelfth centuries include Priscian, Nonius Marcellus, Servius's commentary on Vergil, and a rare commentary on Persius by Remigius of Auxerre. ${ }^{56}$

There are two manuscripts of the $B C$ and $B J$ still extant which have an association with St Peter. The first of these, MS Oxford, Bodleian Library, Rawlinson G.44, has been dated to the late eleventh century, while the glosses in it have been dated to the twelfth century. ${ }^{57}$ The connection with St Peter is established by an inscription on fol. 1r which states: 'iii Septembris ANNO MDLXXIIX repperi IN BIBLIOTHECA GANDAUENSI AD S. PETRUM' ('on 3 September in the year 1578 I found «this book) in the library in Ghent at St Peter'). The date 1578 is noteworthy in light of the later history of this monastery; St Peter was first sacked by Calvinist extremists during the 'Beeldenstorm' movement which swept over Flanders in September 1566, and then subjected to repeated vandalism and looting

\footnotetext{
${ }^{53}$ For discussion of its holdings, see A. Derolez, 'Scriptorium en bibliotheek tijdens de Middeleeuwen', in Ganda \& Blandinium: De Gentse abdijen van Sint-Pieters en Sint-Baafs, ed. G. Declercq, Ghent, 1997, pp. 14760. For a list of surviving manuscripts, numbering some 68 books, see Derolez et al. (n. 46), VII, pp. 140-4. ${ }^{54}$ See Horace, Carminum liber quartus ex antiquiss. manuscriptis codicibus, cum commentariis falso adhuc Porphyrioni et Acrioni adscriptis, ed. Jacob Cruq, Bruges, 1566, p. 4. The most important of these is the socalled Blandinius uetustissimus; for the importance of its readings in reconstructing the text of Horace, see Horace, Opera, $4^{\text {th }}$ ed., ed. D. R. Shackleton-Bailey, Munich, 2001, pp. iii-iv, and E. Courtney, 'The Transmission of the Text of Horace', in Brill's Companion to Horace, ed. H.-C. Günther, Leiden, 2013, pp. 547$60(550-1)$.

${ }^{55}$ For the text of the anathema see n.69 below; it is found in MSS Oxford, Bodleian Library, D'Orville 145 (Hyginus, 11th century), fol. 66 ${ }^{\mathrm{v}}$; Leiden, Universiteitsbibliotheek, BPL 88 (Martianus Capella, $9^{\text {th }}$ century), fol. 2 ; BAV, Reg. lat. 1987 (Martianus Capella, 9th and 11th century), fol. 146v; and Escorial, Real Biblioteca del Monasterio de San Lorenzo, M.III.14 (Nonius Marcellus, 11th century), fol. $2^{\mathrm{r}}$, and L.III.33 (Vegetius, 10th century, with 11th-century additions), fol. $78^{\mathrm{r}}$, as well as in Leiden, Universiteitsbibliotheek, LIP 26 (f. $1^{\mathrm{r}}$ ) and Vat. lat. 3325 (discussed below).

${ }^{56}$ Discussed in detail in my forthcoming article 'The Ghent Manuscript of Terence and its Intellectual Environment'.

${ }^{57}$ See Munk Olsen (n. 18), II, p. 339. See further R. W. Hunt and F. F. Madan, A Summary Catalogue of Western Manuscripts in the Bodleian Library at Oxford, 7 vols, Oxford, 1895-1953, III, p. 350 (no. 14775).
} 
during the period of the Calvinist republic in Ghent, which lasted from $1577 / 8$ to $1584 .^{58}$ There is no other evidence to tie the manuscript specifically to St Peter in the Middle Ages, although the script has been identified as Flemish, ${ }^{59}$ and there is certainly no objection to claiming a provenance from St Peter simply because another manuscript from there still exists; as the examples of Horace and Martianus Capella show, the library seems to have possessed multiple sets of some authors.

An original cover seems to have been provided by two badly worn folios (fols 1 and 68) from a lectionary containing biblical readings for feasts, dated to the tenth century; ${ }^{60}$ another extra folio (fol. 67) contains a number of Latin texts, probably grammatical, written in a scrawling and highly abbreviated script. The book itself is relatively small, with pages measuring 11 by $17 \mathrm{~cm}$, and shows many signs of use, including the scholia; by way of contrast, the other classical manuscript from St Peter now in Oxford, that of Hyginus (MS Oxford, Bodleian Library, D’Orville 145), is almost pristine, and shows very few signs that it was ever studied or read. Like the manuscript from St Bavon, Rawlinson G.44 is a codex mutilus suppletus. The point where the missing text from the $B J$ needed to be inserted fell 5 words after the conclusion of fol. $62^{\mathrm{v}}$; the corrector, whose hand has been dated to the second half of the twelfth century, ${ }^{61}$ inserted 3 folios after this containing the five words and then the missing text, and erased the extraneous five words at the top of fol. $66^{\mathrm{r}}$ to produce a complete text of the $B J$.

Rawlinson G.44 contains a number of interlinear and marginal glosses, particularly at the start of the $B C$, and a detailed ' $T$ ' map at fol. $17^{\mathrm{v}}$, the last page of the second gathering in the manuscript; unusually, this map is not found in the $B J$, but part way through the $B C$, in the middle of Caesar's speech, ${ }^{62}$ and it contains a number of interesting features which will be discussed below. The scholia themselves are a mixture of nonsensical remarks and what may be inspired guesswork; thus on fol. $9^{\mathrm{r}}$, in a gloss on the consular elections at the comitia $(B C$ 24.1), which have already been discussed with respect to the Anonymus Amandensis, the scholiast in Rawlinson G.44 remarks:

\footnotetext{
${ }^{58}$ See J. Van de Wiele, 'De zestiende eeuw; De Sint-Baafsabdij afgeschaft en gesloopt, de Sint-Pietersabdij een ruïne', in Ganda \& Blandinium: De Gentse abdijen van Sint-Pieters en Sint-Baafs, ed. G. Declercq, Ghent, 1997, pp. 73-84.

${ }^{59}$ See O. E. Pächt and J. J. G. Alexander, Illuminated Manuscripts in the Bodleian Library, Oxford, 3 vols, Oxford, 1966-73, I, p. 20.

${ }^{60}$ For the date see Hunt and Madan (n. 57), III, p. 350. P. Saenger, Space between Words: The Origins of Silent Reading, Stanford CA, 1997, who assumed that this manuscript was written in St Peter under Wichard, also seemed to suggest that the fly-leaves were a product of that scriptorium; he contrasted their script, which he defines as 'written in hierarchical word blocks of fewer than fifteen characters in length' with the (fully) separated script which he attributed to the reform of the scriptorium under Wichard (pp. 198, 200).

${ }^{61}$ Munk Olsen (n. 18), II, p. 339.

${ }^{62}$ Fol. $17^{\mathrm{r}}$ concludes with $B C 51.18$, and the text resumes on fol. $18 \mathrm{r}$.
} 
comitia uocantur quaedam festiua tempora in quibus eligebantur consules. dicuntur comitia a cometa, stella illa quae solebat apparere in mucatione regum, et illa festa bis contigerunt in anno; scilicet in aetate et in hieme.

[Comitia is the name of certain festive times during which consuls used to be elected. Comitia are named after the comet, that star which customarily appeared when there was a succession in the monarchy, and those feasts occurred twice in a year; that is in the summer and the winter.]

On fol. $10^{v}$, when explaining the lex Plautia under which Catiline was examined by the magistrate L. Paullus ( $B C$ 31.4), the scholiast provides the following comment:

lex plaut[ic]ia dampnatur illos qui poterant probari coniurationem fecisse contra rem publicam.

[The lex Plautia condemned those men who could be proven to have made a conspiracy against the res publica.]

Strictly speaking, the lex Plautia de ui, as it is properly known, was most probably a broader law, passed in order to indict Roman citizens for 'armed attacks on the senate or the magistrates, the occupation of public squares by armed men, the damaging of, or setting fire to, public buildings and the raising of mobs for these purposes'. ${ }^{63}$ The explanation of it given here, as directed against those who conspired against the res publica, may thus be a case of guesswork on the part of the scholiast; nevertheless, we also know from early sources that it may have been used to prosecute some of Catiline's co-conspirators and others accused of joining in his conspiracy, ${ }^{64}$ so that it is at least possible here that the scholion preserves a confused memory of an earlier comment. ${ }^{65}$

As noted, fol. $17^{\mathrm{v}}$ in Rawlinson G.44 was originally left blank, most probably for the ' $\mathrm{T}$ ' map which now occupies it, but it also contains a number of additional materials in the twelfth-century glossing hand. ${ }^{66}$ At the top of the folio where there was blank parchment remaining above the map, an accessus to the $B C$ was written; it occupies five long lines at the

\footnotetext{
${ }^{63}$ W. Nippel, 'Vis', in Brill's New Pauly, ed. H. Cancik and H. Schneider, XV, Leiden, 2010, cols 462-3.

${ }^{64}$ See the comments in the anonymous Inuectiua in Ciceronem, attributed to Sallust and already known to Quintilian, that Cicero fined certain conspirators while he made judgements under the lex Plautia ([Sallust], Inuectiua in Ciceronem, 2.3), or those in the late antique Scholia Bobiensia (p. 19, 5), that P. Sulla, whom Cicero was defending against accusations of joining in the same conspiracy, was tried by a jury assembled at the same time for another (aborted) trial under this law.

${ }^{65}$ In later commentary traditions the explanation of the lex Plautia became much moe confused; for Renaissance views, see R. W. Ulery, 'In the Margins of Sallust. Part II', in Antiquaria a Roma. Intorno a Pomponia Leto e Paolo II, Rome, 2003, pp. 13-33 (26) [I am grateful to the anonymous reviewer for IJCT for this reference]. ${ }^{66}$ A black and white image of fol. $17^{\mathrm{v}}$ is available on the Bodleian Library's 'Luna' website (http://bodley30.bodley.ox.ac.uk:8180/luna/servlet).
} 
top of the page, then splits apart into two columns of decreasing width after it touches the diagram. The accessus is of Ulery's type 1, beginning: 'In principio uniuscuiusque libri tria maxime requiri solent, scilicet intentio, materies, utilitas' ('At the beginning of each and every book three matters are usually asked about; that is the [work's] aims, the subject matter, the usefulness'); it then proceeds to define these three qualities in terms of the contents of the work and its broad meaning. ${ }^{67}$ Around the rim of the map itself a second circle was drawn, approximately $0.4 \mathrm{~cm}$ distant, and in the intervening space excerpts from Book IX of Isidore's Origines, defining military structures, were written by the same scribe in two lines in a circular fashion.

Finally, the map itself is noteworthy for its orientation as well as its relationship to the text. Instead of having 'Asia' (top), 'Europa' (lower left), and 'Africa' (lower right), the map places 'Africa' (left) and 'Europa' (right) at the top, and has 'Asia' occupying the lower half. Place names taken from the geographical excursus of the $B J(B J 17-19)$ are written by the same scribe in the section 'Africa' in an apparent attempt to indicate their spatial relationship; quite noteworthy is the second line from the bottom which reads 'syrtes · lepis [sic] · syrtes', as the corresponding text of the $B J$ reads 'ac deinceps duae Syrtes interque eas Leptis' ('and from there are the two Syrtes, and between them Leptis'; BJ 19.3)..$^{68}$ In contrast 'Europa' was left largely empty, with only Hispania indicated at the top and Roma at the bottom (more text from Isidore Book IX occupies the intervening space), and in 'Asia' besides egiptus ('Egypt') only tiro et sido appear (most probably corrupt forms for Tyre and Sidon), so that the reader's attention is naturally focused on the part of the map containing Africa.

As in the case of the glosses, it is very difficult to determine whether this map is the original creation of the scribe, or rather is a copy of another manuscript. Nevertheless, the originality of thought in it, especially the orientation, is striking. If the dating of its labels and glosses to the twelfth century is correct, then Rawlinson G.44 provides an important early example of a textually annotated ' $\mathrm{T}$ ' map from the Sallust tradition, which is much closer to slightly later manuscripts, such as that contained in Deventer, SAB, 11 F 1 (discussed below), than that in the St Amand witness, or indeed the very rudimentary map contained in the other witness from St Peter, Vat. lat. 3325.

\footnotetext{
${ }^{67}$ E.g.: 'Materia uero huius operis est catilina ceterique coadiutores coniurationis suae' ('the subject matter of this work is Catiline and the other helpers in his conspiracy').

${ }^{68}$ Although this device also appears in other manuscripts, predominately of the second part of the 12th century. Thus, MS Oxford, Bodleian Library, Rawlinson G.43, a 10th-century manuscript perhaps from the south of France, has a 'T' map on fol. $56^{v}$ as an addition, dated by Munk Olsen (n. 18), II, p. 338, to the second half of the 12th century, and like Rawlinson G.44, this map also writes 'Syrtes Leptis Syrtes', in this instance just below the Nile. See also the discussion below of MS Deventer, SAB, $11 \mathrm{~F} 1$.
} 
MS Vatican City, BAV, Vat. lat. 3325, is a tenth-century manuscript of the $B C$ and $B J .{ }^{69}$ Its early ownership by St Peter is shown by the heavily erased anathema, probably dating to the twelfth century, on fol. $1 \mathrm{r} ;{ }^{70}$ a later hand wrote in capitals 'LIBER SC PETRI DE BLANDINIO MONASTERIO' ('Book of the monastery of St Peter at Blandinium') in the lower margin of fol. $1^{v}$ and $2^{r}$, and a variant of this on fol. $3^{r}$. Other indications of an early association with St Peter may be provided by two discarded leaves from an early tenthcentury missal used as guards at fols $\mathrm{i}$ and 52, which are written in an Anglo-Saxon script ${ }^{71} \mathrm{St}$ Peter is well known for its connections with the Anglo-Saxon ecclesiastical world, and is especially associated with St Dunstan, who spent over a year of exile there c. 956-7. ${ }^{72} \mathrm{~A}$ discarded leaf used as second guard at the end of the manuscript, fol. 51, contains the text of Rithmus de Ioseb patriarcha, or 'Poem concerning the patriarch Joseph'. ${ }^{73}$ This leaf also contains a small excerpt from a commentary on the Psychomachia of Prudentius sometimes attributed to Remigius of Auxerre, the earliest copy of which appears in a manuscript from St Amand $;^{74}$ the script of this excerpt is very close to that of the scribe who provided the supplementary text from the $B J$ (see below). ${ }^{75}$ The entire manuscript was in Rome by 1600 , when it came into the possession of the Vatican library from the estate of the Italian collector Fulvio Orsini (1529-1600). ${ }^{76}$

As noted, Vat. lat. 3325 is a codex mutilus suppletus; the $B J$ originally concluded 12 lines down fol. $50^{\mathrm{r}}$, and the bottom half of this page and the following verso were left blank; the

\footnotetext{
${ }^{69}$ A comprehensive description is provided in the latest (2010) volume of Les manuscrits classiques latins de la Bibliothèque Vaticane; see Pellegrin et al. (n. 44), III.2, pp. 260-1. See also Munk Olsen (n. 18), II, pp. 355-6. ${ }^{70}$ Edited in Pellegrin et al. (n. 44), III.2, p. 261; it now reads: 'liber Sancti Petri Gandensis ecclesiae; Seruanti bedictio [sic], tollenti maledictio. Qui folium 〈ex eo tuler〉it uel 〈curtau〉erit, anathema 〈sit〉' ('a book of the church of St Peter of Ghent. A blessing on whoever preserves it, a curse on whoever steals it. He who removes a folium or cuts off part of it, let him be excommunicated').

${ }^{71}$ Pellegrin et al. (n. 44), III.2, p. 260. Published in H. M. Bannister, 'Liturgical Fragments', Journal of Theological Studies, 9, 1908, pp. 398-427 (412-21), who attributes them, however, to an Irish scribe. For general discussion of the presence of English manuscripts in Flanders at this period, see P. Grierson, 'The Relations between England and Flanders before the Norman conquest', Transactions of the Royal Historical Society, $4^{\text {th }}$ series, 23, 1941, pp. 71-112 (108-12).

${ }^{72}$ For links between Flemish monasteries and Canterbury in this period, see Grierson (n. 71) and S. Vanderputten, 'Canterbury and Flanders in the Late Tenth Century', Anglo-Saxon England, 35, 2006, pp. 21944. For Dunstan's sojourn at St Peter, see M. Winterbottom and M. Lapidge, The Early Lives of Dunstan, Oxford, 2012, pp. xxxiii-xxxiv and cxxv-cxxx, for the hagiographic work Lectiones in depositione S. Dunstani by Adelard of Ghent. See also the early 12th-century account of Dunstan's exile by Eadmer of Canterbury (n. 28), pp. 100-3.

${ }_{73}$ Described and edited by F. Stella, 'Il ritmo de Ioseph patriarcha di Segardo Audomarense: edizione dal Vat. lat. 3325 (Blandiniensis)', Filologia medio-latina, 5, 1998, pp. 279-90.

${ }^{74}$ Now MS Valenciennes, BM 413 (9c). The text corresponds to the commentary on Prudentius, Psychomachia 8 and 10 printed in J. M. Burnam, Commentaire anonyme sur Prudence d'apres le manuscrit 413 de Valenciennes, Paris, 1910, p. 88. For the diffusion of this commentary tradition and the question of authorship by Remigius, see S. O'Sullivan, Early Medieval Glosses on Prudentius' Psychomachia: The Weitz Tradition, Leiden, 2004, pp. 23-7.

${ }^{75}$ The hands are so similar that F. Stella concluded wrongly that this text formed the conclusion of the supplementary text for the $B J$; see Stella (n. 73), p. 182.

${ }^{76}$ Pellegrin et al. (n. 44), III.2, p. 261.
} 
missing text of $B J$ 103.2-112.3 was then written by a scribe of the eleventh or twelfth centuries in the remaining space, ${ }^{77}$ and an insertion mark was placed at the appropriate place on fol. $49^{v}$ for the reader. The hand of this addition is similar not only to the isolated gloss from the Prudentius commentary on fol. $51^{\mathrm{r}}$, but also of that of many of the other glosses which are scattered throughout the manuscript, and will be discussed below. The ' $\mathrm{T}$ ' map in Vat. lat. 3325 occurs on fol. $24^{\mathrm{r}}$, which contains the first part of the geographic excursus beginning: 'In diuisione orbis terrae plerique in parte tertia Africam posuere' (BJ 17.3). The map is very rudimentary and seems to have been made at some stage after the text was copied; at the bottom of the right-hand margin a circle with a diameter of approximately $3 \mathrm{~cm}$ was drawn and only the names of the standard three continents and two rivers (Tanais and Nilus) were inscribed, together with cardinal directions written around the outer rim.

The manuscript, which is given the siglum $R$ in modern discussions, is not considered an important witness for establishing the text of Sallust, even though it is relatively early. ${ }^{78}$ Like other early manuscripts of Sallust, however, it does in fact exhibit many archaic features with regard to Latin orthography and morphology, and in this regard the pattern of the corrections in Vat. lat. 3325 becomes relevant to this discussion. Medial 'i' or 'e' are sometimes found spelled with a ' $u$ ' in Vat. lat. 3325, particularly in superlative and gerundive forms (e.g., 'optumo' for 'optimo', 'capiundae' for 'capiendae', or 'existumans' for 'existimans'), ${ }^{79}$ archaic forms of the accusative plural in the third declension are found throughout (e.g., 'ciuis' for 'ciues'), and variant declensional forms are used (e.g., 'senati decretum' instead of 'senatus decretum'). A corrector (or successive correctors) noticed these earlier forms, and emended some, though by no means all of them. In several of the instances where an 'is' accusative plural ending is found, a corrector added a small loop at the top of the shaft of the 'i', converting it to 'e', ${ }^{80}$ while in one place where Sallust wrote 'senati decretum', the phrase 'uel tus' ('or tus') is added above the ending of the first word. ${ }^{81}$ Still other corrections in Vat.

\footnotetext{
${ }^{77}$ For these dates see ibid. Munk Olsen (n. 18), II, p. 356, dated the addition to the 12 th century.

${ }^{78}$ It is not mentioned by Reynolds in his discussion of the stemma in Reynolds, Texts and Transmission (n. 1), nor is it used for his edition: Sallust, Catilina, Iugurtha, Historiarum Fragmenta Selecta; Appendix Sallustiana, ed. L. D. Reynolds, Oxford, 1991, although he does suggest it may be useful for reconstruction of the lacuna in Reynolds, 'The Lacuna' (n.12). Kurfess uses it occasionally, grouping it in the family 'Y'; see Sallust, Catalina, Iugurtha, fragmenta ampliora post A.W. Ahlberg, $3^{\text {rd }}$ edition, ed. A. Kurfess, Stuttgart, 1991, and it was also used by A. Ernout, Salluste: Catilina, Jugurtha, fragments des Histoires, $7^{\text {th }}$ edition, Paris, 1967.

${ }^{79}$ Spellings are, however, quite inconsistent; thus, on fol. $3^{\mathrm{r}}$, Vat. lat. 3325 has both 'capiundae' (BC 5.6) and 'accipiendis' ( $B C$ 6.5). Occasionally this type of archaic form was transmitted in other, later manuscripts, slipping through apparent attempts to modernize spellings; thus, on fol. 15 $5^{\mathrm{v}}$, Valenciennes, BM 549 reads 'optumum' ( $B C 57.5$ ), although on the next page it reads 'optimum' ( $B C 59.3)$.

${ }^{80}$ Clear examples occur on fols $14^{\mathrm{r}}$ ('talis'; $B C 51.17$ ) and $18^{\mathrm{r}}$ ('montis, cohortis'; $B C$ 59.2).

${ }^{81}$ On fol. $10^{\mathrm{r}}(B C 36.5)$.
} 
lat. 3325 correspond to readings in the manuscripts from St Amand and Marchiennes, ${ }^{82}$ and while it is impossible to date any of these amendments accurately, or to assign them to one individual scholar working on the manuscript, it is also noteworthy that in the replacement passage for the $B J$ there are a number of places where the readings in Vat. lat. 3325 correspond to those in the Valenciennes manuscript. ${ }^{83}$

Vat. lat. 3325 has relatively wide margins, and in some folios medieval scholars working on the text took advantage of these to add material. Often contractions for NOTA ('take note') are found, or else single words or short phrases excerpted from Sallust are rewritten in the opposite margin in the same forms as they appear in the text; this type of annotation is found particularly for the opening 25 chapters of the $B C$ (fols $2^{v}-7^{v}$ ), and later for the speech of $C$. Memmius in the $B J\left(B J 31\right.$; fols $\left.27^{v}-28^{v}\right)$. At various points different scribes writing in a variety of styles have also provided sub-headings for sections of the text. On fol. $3^{\mathrm{r}}$, in the margin opposite the brief description of the history of Rome beginning 'Vrbem Romae...condidere atque habuere initio Troiani' ('in the beginning the Trojans founded and held the city of Rome'; $B C$ 6.1), a scholiast wrote 'origo Romae' ('the origin of Rome'); on fol. $19 \mathrm{v}$, opposite the conclusion of the prologue to the $B J$, which is not specially marked in the text, another hand, similar to that of the main scribe, wrote 'explicit prologus' ('here ends the prologue'); while the beginning of two speeches later in the $B J$ are also marked by scholiasts. $^{84}$

Ultimately, the brevity of these scholia and the presence of different hands makes it extremely difficult to ascribe this activity to one particular period. The one exception to this, however, comes with the highly characteristic script of the supplementary text (denoted here $\Sigma$ ), which resurfaces at various points throughout the manuscript, and which appears to be the work of the same scribe. To begin, on fol. $2 \mathrm{r}$ a hand very similar to that of the main hand of the text had filled the upper margin, above the opening words of the $B C$, with the preliminary

\footnotetext{
${ }^{82}$ On fol. $3^{\mathrm{r}}$ the corrector in Vat. lat. 3325 places inversion marks over the words 'sapientiae parum' (BC 5.4), corresponding to the reading of Valenciennes 549 and Douai 747; on fol. 13 ${ }^{\mathrm{v}}$ the corrector places them over 'reges atque populum' ( $B C 51.4)$, corresponding to the original reading of Valenciennes 549 . On fol. $5^{\mathrm{v}}$ the corrector adds 'erat' above the line at the end of the phrase 'in Italia nullus exercitus' $(B C$ 16.5), coinciding with the reading in Valenciennes 549 and Douai 747; likewise on fol. $6^{\mathrm{v}}$ the corrector glosses the phrase 'uictoria in manu nobis est' ( $B C$ 20.10) with 'uel uobis'; Valenciennes 549 and Douai 747 both read 'uobis in manu' here.

${ }^{83}$ In addition to those variants noted in other manuscripts in the editions of Reynolds and Kurfess, Vat. lat. 3325 and Valenciennes 549 share the following: they add 'esse' after 'id' in the phrase 'id imminutum' (BJ 110.3), 'amicitia' after the phrase 'semper apud me integra' (BJ 110.4), and omit 'uobis' from the phrase 'quando uobis ita placet' (BJ 110.7).

${ }^{84}$ On fol. $42^{\mathrm{v}}$, at the beginning of Marius's address to a 'contio' of the Roman people (BJ 85), a scholiast writing in a script with Gothic features noted: 'Oratio Marii consulis ad populum Romanum'; on fol. $49^{\mathrm{r}}$, at the start of Sulla's speech to Bocchus ( $B J$ 102.5-11), another hand, possibly that of the scribe of the additional text, wrote: 'oratio... ad regem b...' (some text is lost here due to cropping). For the presence of similar subheadings for the $B J$ in MS Munich, BSB, clm 14477, see Cardelle de Hartmann (n. 11), p. 10.
} 
wording of an accessus of type 2 , as defined by Ulery; ${ }^{85}$ without, however, responding with answers relevant to the $B C$. On the opposite page, fol. $1 \mathrm{v}$, which is a guard-leaf containing a work known as Rescriptum ad Iordanem contra epistulas Senecae by Honorius, ${ }^{86}$ and a further (apparently unrelated) scholion by the main hand of Sallust, $\Sigma$ used a small blank space to write an accessus of type $1,{ }^{87}$ beginning 'in principio cuiuscumque libri principaliter secundum boetium tria requirenda sunt: intentio, materia, finalis causa' ('At the beginning of whatsoever book, according to Boethius, three matters should be asked about; the [work's] aims, the subject matter, the final intention'), then continuing with an incomplete reference to the 'partes philosophiae' ('divisions of philosophy'). Like the main gloss, however, $\Sigma$ does not answer these topics with descriptions of the $B C$.

Vat. lat. 3325 also transmits an accessus for the $B J$, written in the upper margin of fol. $19 \mathrm{r}$ above the prologue of this work in a glossing hand which is now faded and difficult to read; it begins: 'Intentio huius proemii est reprehendere ignauos quorum multi erant qui conquerebantur de natura' ('the intention of this prologue is to castigate foolish men, of whom there were many who used to complain about their nature'), paraphrasing the opening words of $B J 1.1$ ('Falso queritur de natura sua genus humanum'). As noted earlier, this accessus is found in a twelfth-century Norman manuscript of Sallust now in the Vatican (BAV, Ottob. lat. 1843), ${ }^{88}$ noteworthy also for including a brief extract from the Anonymus Amandensis, and so these coincidences may provide further (albeit indirect) evidence for the many of the corrections in this manuscript being based on scholarship originating in $\mathrm{St}$ Amand.

On fols $5 \mathrm{v}$ and 6r $\Sigma$ provides glosses on particular words taken from Isidore's Origines. As a gloss on 'ex coloniis et municipiis' $(B C 17.4)$ in the lower margin of fol. $5 \mathrm{v}, \square$ cites almost verbatim the corresponding definitions from Book 15:

Colonia est quae defectu indigenarum nouis cultoribus adimpletur, unde et colonia a cultu agri est dicta. Municipium a muniis id est officiis, eo quod tantum munia id est tributa debita uel munera reddant. Nam liberales et famosissimae causae, et quae ex principe proficiscuntur, ibi non aguntur. haec enim ad dignitatem ciuitatum pertinent [= Isidore, Origines 15.2.9-10].

\footnotetext{
${ }^{85}$ Posing the initial questions 'Quis, quid, ubi, quibus auxiliis, quomodo, quando'; see Osmond and Ulery (n.4), p. 194.

${ }^{86}$ For discussion, see G. H. Brown, 'Anthologia Latina 666 in Codices Vat. Lat. 3325 and Monacens. CLM 14613', CP 68 (1973), pp. 213-24.

${ }^{87}$ Found with slightly different wording in Rawlinson G.44; see above.

${ }^{88}$ Described by Munk Olsen (n. 18), II, p. 350; see further p. 313 (\# 107), where this manuscript is the only one cited for this particular text.
} 
A colony (colonia) is what is filled with new inhabitants (cultores) when there are no indigenous people. Hence also a 'colony' is so called from the tilling (cultus) of a field. A free town (municipium) is named from 'official functions' (munia), that is 'obligations', because they yield only these functions, that is, as the owed tributes or services (munera). The most notorious court cases and those involving a person's freedom, as well as those that proceed from the sovereign, are not conducted there; these belong to the jurisdiction of the city (ciuitas). ${ }^{89}$

On the opposite page (f. 6r) $\nabla$ also glosses two legal terms, ambitus and repetundarum (BC 18.2-3) with definitions from Book 5 of Isidore, ${ }^{90}$ writing both in the margin and interlineally. The next lengthy gloss by $\nabla$ or a hand which is quite similar occurs in the upper margin of fol. $17 \mathrm{r}$, where a passage from Servius' commentary on Vergil is cited which in turn cites the phrase of Sallust to which it is linked; ${ }^{91}$ next to this quote the heading 'SERUIUS SUPER UIRGILIUM' ('Servius concerning Vergil') is written in majuscules. In the top margin of fol. 30v Paulus Diaconus' epitome of Pompeius Festus is cited as a gloss on the $B J,^{92}$ also with a heading written partly in majuscules: 'Paulus ex libro FESTI POMPEII ad karolum' ('Paulus from the book of Pompeius Festus dedicated to Charlemagne').

This process of glossing Sallust with relevant excerpts from authorities such as Servius, Priscian, or Isidore, and prefixing the gloss with an indication of its source, seems to be a precursor of the more developed commentary traditions described by Ulery; it can be found in eleventh- or twelfth-century glosses written in manuscripts from the German linguistic area, including the eleventh-century witness from Regensburg discussed by Cardelle de Hartmann, MS Munich, BSB, clm 14477 (where they appear only for the $B C$ ), ${ }^{93}$ and the late tenthcentury manuscript from Echternach in Luxembourg, now MS Paris, BNF, lat. $10195 .{ }^{94}$ But it should also be noted that it was a common practice in other manuscripts from the scriptorium at St Peter, and in particular is found throughout the Terence manuscript, MS Leiden, Universiteitsbibliotheek, LIP 26, in hands dating probably to late eleventh or early twelfth

\footnotetext{
${ }^{89}$ Adapted slightly from the translation of S. A. Barney, W. J. Lewis, J. A. Beach and O. Berghof, The Etymologies of Isidore of Seville, Cambridge, 2006, p. 306.

${ }^{90}$ Isidore, Origines, V.26.21 and V.26.23.

${ }^{91}$ Servius, Aeneid, I.159, which cites $B C 55.3$ ('est in carcere locus quod Tullianum appellatur').

${ }^{92}$ Pompeius Festus p. 395.3-5 [Lindsay], glossing BJ 38.9 ('sub iugum missurum') with an account of the construction of the yoke.

${ }^{93}$ See Cardelle de Hartmann (n. 11), p. 9 and n.32; for the dating of these glosses to the 11 th or 12 th century, see p. 8.

${ }^{94}$ See Munk Olsen (n. 18), II, pp. 343-4, dating the various glosses in this manuscript to the 10th-12th century, and for an illustration showing a gloss to BJ 12.5 ('tugurio mulieris ancillae') from Servius, Aeneid, I.409, E. Chatelain, Paléographie des classiques latins, 2 vols, Paris, 1884-1900, I, pl. 53.
} 
century. ${ }^{95}$ The glossing in Vat. lat. 3325 may thus reflect the intellectual environment of this scriptorium, rather than being a specific offshoot of the Sallust manuscript tradition.

\section{c) St Omer}

In addition to our surviving witnesses, there are other indications that the text of Sallust's two works circulated widely in Flanders in this period. The description in a lost catalogue from the early twelfth century of the library of St Bertin, on the outskirts of the town of St Omer, shows that this monastery possessed a manuscript of Sallust among its substantial collection of books, which also included other Latin literary works from the standard curriculum. ${ }^{96}$ This manuscript presumably contained both the $B C$ and $B J$, although it is long since lost. The Bibliothèque municipale of St Omer does in fact still possess a twelfth-century manuscript from the nearby Cistercian abbey at Clairmarais, which was founded around $1140,{ }^{97}$ and which contains extracts from these two works in a florilegium, but these in fact belong to a composite work known as the Florilegium Duacense which is known from two other Cistercian foundations in the vicinity of Douai. ${ }^{98}$

Nevertheless, evidence for the study and use of these two works at St Bertin is provided by their usage in literary works, most notably the Encomium Emmae Reginae, written by a monk from St Bertin in 1041 or 1042. In the assessment of the editor Alistair Campbell, ' $[\mathrm{t}] \mathrm{he}$ Encomiast's borrowings from Sallust are remarkable in that their number and their frequent length makes it certain that he had made a close first-hand study of both the Catilina and the Iugurtha. ${ }^{99}$ The identity of the author as a monk of St Bertin is assured, and regardless of whether the work itself was written in Flanders using the manuscripts of the St Bertin scriptorium, or at the English court in Winchester (as has been argued), ${ }^{100}$ the detailed level of allusion to Sallust's texts throughout this work strongly suggests that the author was familiar with both works well before he started writing the Encomium, and that Sallust was not merely

\footnotetext{
${ }^{95}$ See the discussion of the scholiastic hands $\Sigma$ and $\Sigma 4$ in my forthcoming article 'The Ghent Manuscript of Terence and Its Intellectual Environment'.

${ }^{96}$ See A. Berthod, 'Notice du Cartulaire de Simon, Manuscrit de la Bibliotheque de St. Bertin', Nouveaux mémoires de l'Académie impériale et royale des sciences et belles-lettres de Bruxelles, 1, 1788, pp. 227-31; reprinted in G. Becker, Catalogi bibliothecarum antiqui, Bonn, 1885, pp. 181-4. For a list of classical Latin literary texts from this catalogue, see Munk Olsen (n. 18), III.1, pp. 221-2. For further discusion of the intellectual environment at St Bertin during this period, K. Ugé, Creating the Monastic Past in Medieval Flanders, Woodbridge, 2005, pp. 37-49.

${ }^{97}$ See $D H G E$, XII, cols 1046-8.

${ }^{98}$ For descriptions, see Munk Olsen (n. 18), II, p. 848 ([C. 12] Douai, BM 285, from Anchin), pp. 848-9 ([C. 14] Douai, BM 533, from St Rictrude, Marchiennes), and pp. 867-8 ([C.53.5] St Omer, BM 8, from Clairmarais).

${ }^{99}$ See Encomium Emmae Reginae, ed. A. Campbell, with a supplementary introduction by Simon Keynes, Cambridge, 1998, p. cxi [p. xxix in the original edition]; for his extensive list of clear parallels, see pp. cxi-cxii [pp. xxix-xxx].

As suggested initially by Keynes in Campbell (n. 99), pp. xxxix-xli; see also the recent discussion of E.M. Tyler, 'Talking about History in Eleventh-Century England: The Encomium Emmae Reginae and the Court of Harthacnut', Early Medieval Europe, 13, 2005, pp. 359-83.
} 
regarded at St Bertin as a school text, but as an important model for historiography. One further point to note here is that one of the passages suggested by Campbell as a borrowing in the Encomium (diem locum tempus, BJ 108.2) comes from the omitted passage of the BJ. It may therefore have been the case that St Bertin possessed a very early example of the complete text of the $B J$ (whether integer or suppletus), which first starts appearing in manuscripts from the eleventh century. ${ }^{101}$

The same high esteem may have been why Sallust's $B C$ is also cited twice in the preface to Book II of the Deeds of the Abbots of Saint Bertin by Simon of Ghent (d. 1148), ${ }^{102}$ although this part of the work appears to have been completed after Simon had departed from St Bertin (where he had been abbot until 1136) and had taken up residency in Ghent. ${ }^{103}$ Besides their educational value, the works may have been studied with regard to the geographic excursus in the $B J$ and associated maps; scholarship produced in the collegiate church of St Omer, in particular the Liber Floridus (MS Ghent, Universiteitsbibliotheek, 92), written in 1121, reveals a deep interest in cartography at St Omer at this time. ${ }^{104}$

\section{d) The Deventer manuscript}

Another manuscript which seems to have had an association with Flanders in this period is MS Deventer, Stadsarchief en Athenaeumbibliotheek [hereafter, SAB], $11 \mathrm{~F} 1$. This manuscript probably dates to the late twelfth century and contains both the $B C$ and $B J$, as well as some heterogeneous materials, ${ }^{105}$ including short poems about the game of chess, a cure for baldness and the misery of marrying a poor bride. There is no indication of a monastery library or other early provenance, but on the final folio (fol. $71^{\circ}$ ) there is an epitaph which has

\footnotetext{
${ }^{101}$ See Reynolds (n. 12), p. 59.

${ }^{102}$ See the partial edition of O. Holder-Egger, 'Simonis gesta abbatum S. Bertini Sithiensium', in Monumenta Germaniae Historica, Scriptores XIII, Hanover, 1881, pp. 635-63 (644), with references to BC 20.4 and 2.4.

${ }^{103}$ See R. F. Berkhofer, Day of Reckoning: Power and Accountability in Medieval France, Philadelphia, 2004, pp.75, 78-9. For discussion of the transmission of this work and its relationship to contemporary social issues and historiography, see also S. Vanderputten, 'Monks, Knights, and the Enactment of Competing Social Realities in Eleventh- and Early-Twelfth-Century Flanders', Speculum, 84, 2009, pp. 582-612, and id., 'Individual Experience, Collective Remembrance and the Politics of Monastic Reform in High Medieval Flanders', Early Medieval Europe, 20, 2012, pp. $70-98$ (esp. p. 73, n.11).

${ }^{104}$ For discussion, see esp. K. De Coene and P. De Maeyer, 'One World under the Sun: Cosmography and Cartography in the Liber Floridus', in Liber Floridus 1121: The World in a Book, ed. K. De Coene, M. De Reu and P. De Maeyer, Tielt, 2011, pp. 90-127.

${ }^{105}$ For descriptions, see Catalogus der Handschriften berustende op de Athenaeum-Bibliotheek te Deventer, Deventer, 1892, p. 39; Munk Olsen (n. 18), II, p. 320; and (partly superseding these), the online description provided by the Koninklijke Bibliotheek at 'Medieval Manuscripts in Dutch Collections' (http://mmdc.nl/static/site/index.html).
} 
been identified as referring to Count Baldwin of Flanders (d. 1119), and on the following verso (which is partly illegible) there is apparently a poem in praise of Flanders. ${ }^{106}$

MS Deventer, SAB, $11 \mathrm{~F} 1$ is a codex integer; it is not glossed, but contains a ' $\mathrm{T}$ ' map on fol. $1 r{ }^{107}$ Africa is found in its usual place on the bottom right-hand side, and the names and wording written within it are sometimes, like Rawlinson G.44, related back to the text of Sallust. Thus just below the Nile appears the phrase 'loca exusta solis ardoribus' ('places scorched dry by the fires of the sun'), which is cited directly from BJ 19.6, while Leptis now appears sandwiched between the syllables Syr and tes, and other place names taken from Sallust's excursus (e.g., Catabathmon, Cyrene, Arae Philenon and so on) are included, although in no particular order. Readers are less likely than those of Rawlinson G.44, however, to have drawn a direct connection between the map and Sallust's text, not only because Africa is still kept in the bottom right corner, but because there are now several place names inscribed within 'Asia' and 'Europa' as well, such as a catalogue of provinces in Asia (beginning with Paradisus and ending with Galilea), as well as a list of cities in Greece, making the whole scheme much more complex.

\section{e) Egmond}

To conclude this section, I will discuss briefly the surviving manuscript from the Dutch monastery of Egmond, now MS Brussels, Bibliothèque royale, 10057-10062-III. ${ }^{108}$ This monastery, in the County of Holland, was founded by monks from Ghent at the beginning of the tenth century; its library was established by Bishop Egbert of Trier (c.950-93) and augmented under successive abbots, including Stephanus (d. 1105). ${ }^{109}$ The manuscript of Sallust, Brussels 10057-10062-III, is the third part of a composite manuscript; this part, originally a separate manuscript, contains the four Catilinarian orations of Cicero as well as the $B C$ and $B J$, and was presented to Egmond during the abbacy of Stephanus by a 'Magister Balduuinus' ${ }^{110}$ This provenance suggests that the manuscript was most probably not written at Egmond; in his comprehensive catalogue, Birger Munk-Olsen conjectured that it came either

\footnotetext{
${ }^{106}$ This information is provided on the 'Medieval Manuscripts in Dutch Collections' website, where it is attributed to 'unpublished institutional documentation'. The Catalogus der Handschriften (n. 105) merely describes the epitaph of Baldwin as 'Epitaphium cujusdam comitis', and notes that the final folio is 'geheel onleesbaar' ('entirely illegible'); Munk Olsen, however, describes its contents as 'en partie illisibles'.

${ }^{107}$ The map is now poorly legible; see the 'Medieval Manuscripts in Dutch Collections' website for a reproduction. There is, however, a useful redrawing of it in J. Keuning, 'XVIth Century Cartography in the Netherlands', Imago Mundi, 9, 1952, pp. 35-63 (36).

${ }^{108}$ See Munk Olsen (n. 18), I, p. 158, and II, p. 319. For the provenance, see also F. Masai, 'Le catalogue d'Egmond et le Bruxellensis 10057-62', Scriptorium, 5, 1951, pp. 121-3.

${ }^{109}$ See A. C. F. Koch, 'Egmond', in $D H G E$, XV, cols 23-7 (23).

${ }^{110}$ An inscription stating: 'Liber magistri balduuini quem dedit ecclesiae ekmundensi' occurs at the top of fol. $59^{\mathrm{r}}$. For the unity of the two separate parts of this manuscript, Cicero and Sallust, see Masai (n. 108), p. 123, n. 40.
} 
from Germany or Belgium. ${ }^{111}$ The manuscript is an integer, although two folios originally containing the beginning of the replacement passage have fallen out. ${ }^{112}$ The historical connection of the abbey with Ghent may not be enough to establish the provenance of this one manuscript more closely, although a handful of readings at its beginning coincide with those in the Valenciennes manuscript and its apograph from Douai, which may indicate some sort of relationship between the texts. ${ }^{113}$

Whether the scholia found throughout the Sallust section of the manuscript were copied in the original scriptorium or later at Egmond is more uncertain. They are likely to be early-the majority of them are written neatly in the margins in a hand similar to that of the principal scribe, and they were also written before a brief account of Italy on fol. $146^{\mathrm{v}}$, at the end of the $B J$, in another hand which has been dated to the twelfth century. ${ }^{114}$ On the other hand, it should also be noted that in the ' $\mathrm{T}$ ' map which appears on fol. $146^{\mathrm{v}}$, the name Ekmundia (i.e., Egmond) is written inside the 'Europa' section, and indeed is the only place-name to be included in the map (apart from Jerusalem).

There is no accessus in this manuscript, and the scholia themselves do not correspond directly to those in surviving manuscripts from the Flemish monasteries, although they illustrate some common tendencies. Many of them are simple definitions of words, ${ }^{115}$ while others cite the works of other authors from the classical curriculum, either directly or through the medium of commentaries ${ }^{116}$ - the opening gloss to the $B C$ on fol. $86^{\mathrm{v}}$ is particularly interesting in this regard, since it cites an extensive note from Servius's commentary on the Aeneid (Servius, Aeneid, V.81). Isidore's definitions of various Roman magistracies and military terms from Book 9 are also found, although not written as a single block of text, but rather written individually in the margins opposite occurrences of the words, ${ }^{117}$ and one of the most interesting features of this commentary is its use of Jerome's chronicle and Orosius's Historiae aduersum paganos as sources of historical information. ${ }^{118}$ A much better idea of the

\footnotetext{
${ }^{111}$ Munk Olsen (n. 18), I, p. 158.

${ }^{112}$ A. Salvatore, 'De duobus Sallusti codicibus Bruxellensibus', Scriptorium, 8, 1954, pp. 38-60 (50).

${ }^{113}$ In $B C 2.1$ all three witnesses read 'in initio, intentus negotio' and 'bonae artis'; in the collation of Brussels 10057-10062-III by Salvatore (n.112) these readings are only attested in the Brussels manuscript.

${ }^{114}$ Munk Olsen (n. 18), II, p. 319.

${ }^{115}$ Thus, on fol. $87^{\mathrm{r}}$ a gloss to 'facinoris' in BC 2.9 reads: 'Facinus et in bono et in malo accipitur' ('facinus is understood both in a good and a bad sense').

${ }^{116}$ For direct citation, Cicero's De inuentione is cited on fol. $87^{\mathrm{v}}$ with respect to $B C 5.4$ 'satis eloquentiae, sapientiae parum' ('Cicero dicit in rhetoricis sapientiam sine eloquentia...' cf. Cicero, De inuentione 1.1), while Vergil's Aeneid is cited on fol. $88^{\mathrm{v}}$ with regard to $B C 7.2$ 'belli patiens' ('Vergilius at patiens operum...'; cf. Virgil, Aeneid, IX.607-8).

${ }^{117}$ Thus, the definitions of quaestor and praetor (Isidore, Origines, IX.4.16) are written in the margin of fol. $91^{\mathrm{v}}$ opposite a usage of 'quaestor pro praetore' ( $B C$ 19.1), although in reverse order to Isidore's text.

${ }^{118}$ On fol. $89^{\mathrm{r}}$ with regard to Carthago in $B C 10.1$ the scholiast cites Jerome, Chronicle 143.22-6 for the number of years from the foundation of Carthage to its surrender. On fol. $146^{\mathrm{r}}$ with regard to the crushing defeat of a
} 
originality of this commentary work and its possible connections to other traditions, including those in Flanders proper, will not be able to be provided until full editions and studies of the other contemporary commentary traditions are available. Nevertheless, it is clear that the scholar who prepared the commentary for this manuscript (if he was not the original scribe himself), was well aware of the need to interpret difficult references in these texts for his audience.

\section{CONCLUSIONS}

The pattern of production of the $B C$ and $B J$ in Flanders matches nicely with the general tendencies already observed for Europe as a whole; that is, manuscripts first start appearing in relatively small numbers in the Carolingian period, and then there is sharp increase in the eleventh and twelfth centuries, before production tapers off again. ${ }^{119}$ Of the manuscripts discussed here, only Vat. lat. 3325 (from St Peter) dates before this period; the other St Peter witness, Rawlinson, G.44, dates to the eleventh century (as does probably the witness from Egmond), but all the rest date to the twelfth century (or even later).

More complex is the question of when the missing text of the $B J$ was added to these manuscripts, and its relationship to scholarship on Sallust in general. Cardelle de Hartmann has noted the appearance of an integer in Germany as early as the first half of the eleventh century, ${ }^{120}$ but the copying process in widely dispersed scriptoria cannot have been even; thus our witness from St Bavon, BAV, Reg. lat. 686, may have been copied in the late twelfth century from an exemplar which lacked the replacement passage, although it was quickly corrected, probably in the same scriptorium. Vat. lat. 3325 at least provides a good example of an early mutilus, supplemented and corrected in the eleventh or twelfth century by a scholiast who also was the source of other notes on the text, but other twelfth-century surviving witnesses, such as Valenciennes, BM 549 (from St Amand), appear with the missing text written in the correct place, making it virtually impossible to determine at what stage in the transmission process this text may have been added. In this context, the evidence provided by the Encomium Emmae Reginae is tantalizing; if we accept the identification by

\footnotetext{
Roman army at Orange mentioned by Sallust at BJ 114.1, the scholiast cites Orosius, Historiae,V.16.3-4, and on Marius's campaign against the Cimbri, to which Sallust refers indirectly at the end of the $B J(B J 114)$, the scholiast cites Jerome, Chronicle, 148.22-4 for the numbers of barbarians killed or captured.

${ }^{119}$ See Osmond and Ulery (n. 4), p. 193; Reynolds, Texts and Transmission (n. 1), p. 345.

${ }^{120} \mathrm{Clm}$ 14477, which she shows had reached the library of St Emmeran by 1080 at the latest; Cardelle de Hartmann (n. 11), pp. 6-7.
} 
Campbell of a borrowing in it from the missing section of the $B J$, then it seems quite possible that a manuscript containing this text was available at St Bertin before 1042.

Developments in scholarship on the $B C$ and $B J$ are also reflected in the manuscripts from Flanders. One of the earliest phases seems to be exemplified by that in Vat. lat. 3325, where the scholiast who added the missing text also appears to have added relevant excerpts from encyclopaedic works, like Priscian or Isidore, or standard literary commentaries such as Servius. This simple type of commentary, which appears ad hoc in its relationship to the text, and which may simply have reflected the interests of the scholiast and the texts available to him at the time, seems gradually to have been superseded by more developed forms attempting to give a systematic exegesis of the text of the $B C$ and $B J$. This latter type is found in the Anonymus Amandensis as well as the manuscript from Egmond, although it is also possible that some of the notes in Rawlinson G.44 were sourced from such a text. And despite the absurdity of some (though by no means all) of the explanations, what characterizes this type of commentary most is the attempt (albeit in an eclectic way) to engage with difficult aspects of the text, such as references to political institutions which had long since vanished, for the benefit of contemporary twelfth-century readers. The same concern seems to be reflected as well in the alterations to archaic forms and spellings in Vat. lat. 3325, which are suggestive of a deliberate attempt to make the text of Sallust more accessible to readers trained only in contemporary Latin forms.

Looked at in broader terms, the distribution of these texts may reflect in some aspects educational policies of the time, in a monastic world which was rapidly changing its place in society. Steven Vanderputten has shown how radically the religious landscape of Flanders altered in the course of the eleventh century, from being dominated by a handful of established Benedictine houses to a place where the number of Benedictine monasteries doubled in the course of fifty years, and new forms of religious life, including secular and regular canons, were expanding rapidly. ${ }^{121}$ Manuscripts such as Vat. lat. 3325, may have been sufficient for the use of scholars studying in prestigious institutions such as St Peter or St Bertin, but for educating monks in these new foundations, like Marchiennes or Egmond, multiple copies needed to be made, and clear explanations provided for readers now curious to know what things like comitia were.

\footnotetext{
${ }^{121}$ Vanderputten, 'Crises of Cenobitism' (n. 13), pp. 262-3.
} 


\section{University Library}

\section{- M M I N E R VA A gateway to Melbourne's research publications}

Minerva Access is the Institutional Repository of The University of Melbourne

Author/s:

Turner, AJ

Title:

Reading Sallust in Twelfth-Century Flanders

Date:

2014-10

Citation:

Turner, A. J. (2014). Reading Sallust in Twelfth-Century Flanders. International Journal of the Classical Tradition, 21 (3), pp.198-222. https://doi.org/10.1007/s12138-014-0344-0.

Persistent Link:

http://hdl.handle.net/11343/282774 